\title{
СИСТЕМА ДЛЯ РЕАЛІЗАЦІЇ МЕТОДА ДІАГНОСТИКИ ПНЕВМОНІЙ ПАСИВНОЮ ЕХОЛОКАЦІЕЮ
}

\author{
А. Є. Апікова, Д. О. Федотов, В. А. Клименкоㄹ, К. О. Яновська ${ }^{1}$ \\ Харківський національний університет радіоелектроніки \\ ${ }^{1}$ Харківський національний медичний університет
}

\begin{abstract}
У статті описано конструкцію обладнання для реалізації способу діагностики пневмонії методом пасивної ехолокації. Діагностика здійснюється завдяки прослуховуванню, ідентифікації та виявленню місця положення джерел патологічних шумів у дихальній системі пацієнта. Пристрій розроблено спеціально для реалізації способу діагностики пневмонії методом пасивної ехолокації та випробувано. Отримані записи акустичних сигналів дихального патерну мають високу якість, сам пристрій зручний та простий у використанні.
\end{abstract}

Ключові слова: пневмонія, аускультація, пасивна ехолокація, дихальний патерн, бронхофонографрія, АЧХ.

\section{СИСТЕМА ДЛЯ РЕАЛІЗАЦИИ МЕТОДА ДИАГНОСТИКИ ПНЕВМОНИЙ ПАСИВНОЙ ЕХОЛОКАЦЕЙ}

\author{
А. Е. Апикова, Д. А. Федотов, В. А. Клименкоㄹ, Е. А. Яновская ${ }^{1}$ \\ Харьковский национальный университет радиоэлектроники \\ ${ }^{1}$ Харьковский национальный медицинский университет
}

\begin{abstract}
В статье описана конструкция оборудования для реализации способа диагностики пневмонии методом пассивной эхолокации. Диагностика осуществляется благодаря прослушиванию, идентификации и выявлению местоположения источников патологических шумов в дыхательной системе пациента. Устройство разработано специально для реализации способа диагностики пневмонии методом пассивной эхолокации и испытано. Полученные записи акустических сигналов дыхательного паттерна имеют высокое качество, само устройство удобно и просто в использовании.
\end{abstract}

Ключевые слова: пневмония, аускультация, пассивная эхолокация, дыхательный паттерн, бронхофонография, АчХ.

\section{SYSTEM FOR IMPLEMENTATION OF METHOD FOR PNEUMONIA DIAGNOSING BY PASSIVE ECHOLOCATION}

\author{
A. E. Apikova, D. O. Fedotov, V. A. Klymenko ${ }^{1}$, K. O. Yanovska ${ }^{1}$ \\ Kharkiv National University of Radioelectronics \\ ${ }^{1}$ Kharkiv National Medical University
}

\begin{abstract}
The article describes the design of equipment for implementing the method of diagnosis of pneumonia by the method of passive echolocation. Diagnosis is done through listening, identify and determine the place of the provisions of pathological noise sources in the respiratory system of the patient. The device is specially designed for implementation of the method of diagnosis of pneumonia by the method of passive echolocation and tested. The recordings of acoustic signals of respiratory pattern are of high quality, the device itself is convenient and easy to use.
\end{abstract}

Key words: pneumonia, auscultation, passive sonar, breathing pattern, bronchophonography, frequency response.

( ) А. Є. Апікова, Д. О. Федотов, В. А. Клименко, К. О. Яновська 
Вступ. Пневмонія є головною інфекційною причиною смертності дітей (15\% усіх випадків смерті серед дітей до 5 років ) в усьому світі. У 2013 році від пневмонії померло 935 тис. дітей у віці до 5 років [7].

Тому своєчасна та точна діагностика цього захворювання має велике значення в лікуванні. Чим раніше виявлено проблему, з якою має справу лікар-пульмонолог, тим більше шансів запобігти ускладнень захворювання.

Для вислуховування дихальних шумів були запропоновані електронні стетоскопи з підсилювачем звуку. Такі стетоскопи не дуже поширені у практиці лікарів з причини високої ціни та слабкої чутності складних шумів. Це пов'язано з тим, що на наш час не існує підсилювачів, спроможних забезпечити однаково добре підсилення усіх частот укупі. Також стетоскоп сконструйований як закрита акустична система, що складається з контактної воронки, закритої мембраною, акустичні властивості якої міняються залежно від сили натиску, полімерних м'яких трубочок та навушників. Крім того, на якість аускультації впливають також шуми серця і зовнішні умови проведення обстеження.

Коли лікар проводить аускультацію, він намагається 3'ясувати місце знаходження джерела патологічних шумів та за характером звуку виявляє вид патології. Від характеру аускультативних звуків залежить клінічний діагноз [9]. Іноді при вислуховуванні виникають звуки, які неможливо ідентифікувати внаслідок їх нечіткості та слабкої сили, або зовнішні шуми, що є завадами. Тоді лікар сумнівається, до якої патології вони належать.

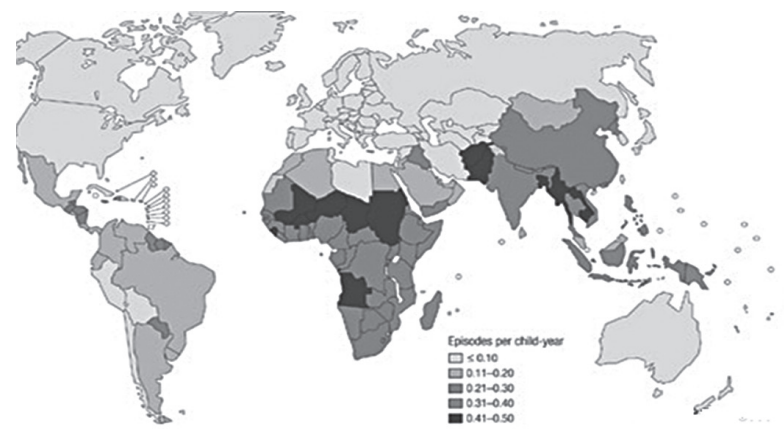

Рис. 1. Розповсюдження у відсотках дитячої смертності від пневмоній у світі [7]

Також для новонароджених та дітей молодшого віку процес аускультації має складнощі та обмеження. При проведенні вислуховування маленька дитина часто плаче, не може виконувати прохання лікаря щодо контрольованого дихання. Не використовують для новонароджених спірометрію та пікфлоуметрію [2].

Для запобігання помилкових діагнозів та поліпшення роботи лікаря при постановці діагнозу у випадку недостатньої кількості даних, ВООЗ запропонувала використовувати наступний алгоритм:

Як видно з алгоритму (рис. 2), при підозрі на пневмонію є рекомендація на проведення рентгенографії. Цей спосіб надає інформацію про розташування запального процесу у легенях пацієнта у вигляді затемнених ділянок. Спосіб досить інформативний, але має побічний ефект у вигляді рентгенівського випромінювання. Провести таке дослідження новонародженому досить складно, оскільки мала дитина постійно рухається та не виконує прохання лікаря.

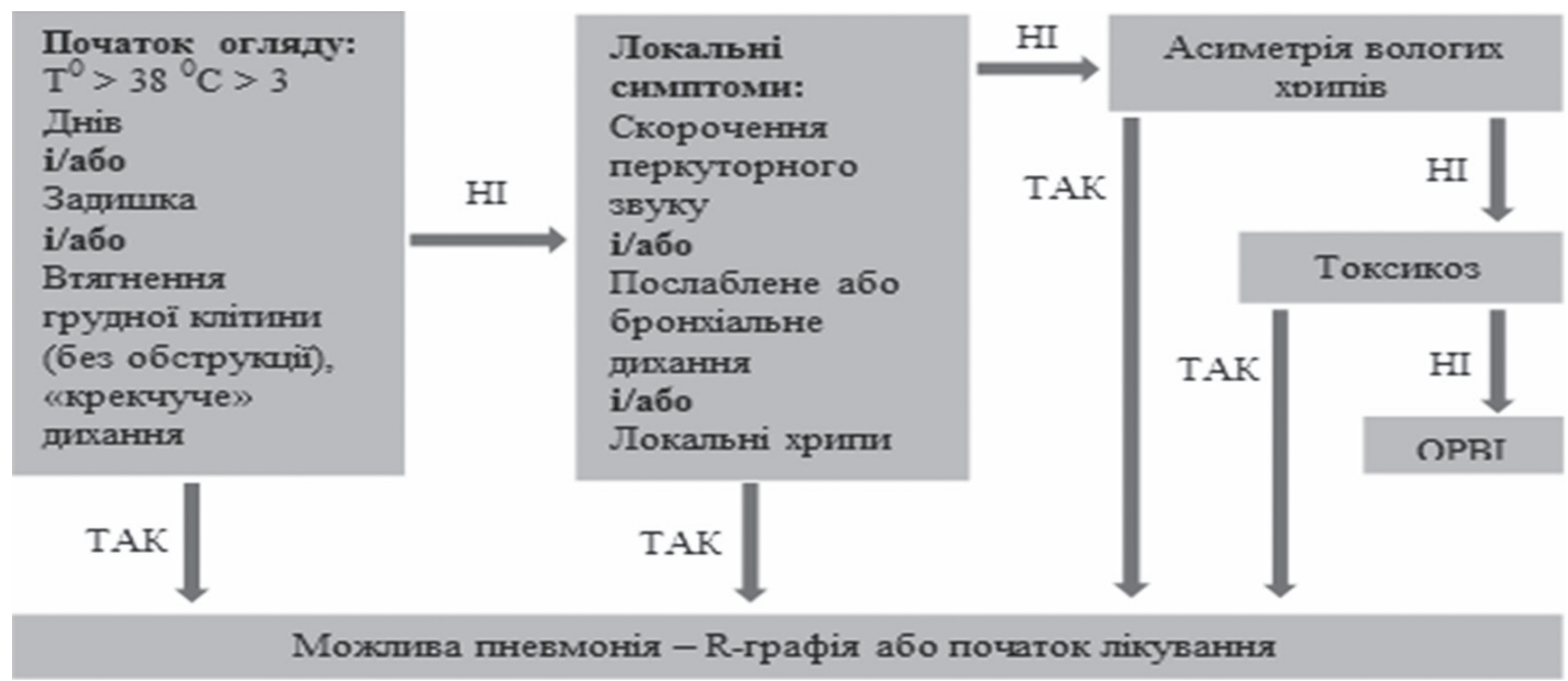

Рис. 2. Алгоритм прийняття рішення при діагностиці бронхолегеневих захворювань 
Крім аускультації та рентгенографії, існують інші досить інформативні та безпечні методи діагностики. До таких методів можна віднести перкусію. Віна полягає у вислуховуванні звучання ділянок грудної клітки при її простукуванні. Для автоматизації процесу на тіло пацієнта подають різні акустичні коливання та намагаються виявити місця запалення за тоном резонансних відкликів. Таким чином можна визначити тонографію, а по ній - стан внутрішніх структур тіла. Проблему автоматизації процесу перкусійного методу вирішили за рахунок апарату Locaphony, котрий дозволив знімати двомірні акустичні зображення патологічних змін внутрішніх органів пацієнта. Принцип роботи цього апарату полягає у тому, що на тіло пацієнта накладають випромінювачі акустичних збуджуючих сигналів і мікрофони. При проходженні через тіло пацієнта, від випромінювача до приймача, акустичний сигнал проникає крізь різні внутрішні структури. При запальних процесах внутрішні органи, зазвичай, збільшуються у розмірах та наповнюються рідинами, наприклад, збільшується кровонаповнення. Тому акустичний сигнал на виході з тіла має змінений тон за наявності патологічних процесів, що дозволяє також визначати розміри органів. Частотний діапазон Locaphony становить від 300 Гц до 3000 Гц, при цьому точність отримуваного зображення патології у площині дорівнює 2-3 мм [11]. Така точність зумовлена розмірами акустичного приймача. Недоліком цього методу є побудова лише двомірного зображення патологічного процесу. Вказаний метод не може виявити глибину залягання запальних процесів та прослухати і ідентифікувати характер звуків, які безпосередньо створюються при пневмонії.

Наступним методом вислуховування акустичних феноменів в легенях пацієнта $є$ бронхофонографія. Це дослідження, засноване на об’єктивному комп’ютерному аналізі різних характеристик дихальних шумів. Метод використовують для обстеження усіх вікових категорій пацієнтів. У ньому візуалізація порушень дихальної системи базується на дослідженні частотно-амплітудних характеристик дихальних шумів. Для реалізації методу створено комп’ютерний акустичний діагностичний комплекс «Паттерн - 01» 3 програмним забезпеченням PatternMAK [5]. Принцип методу полягає у реєстрації дихальних шумів за допомогою акустичних приймачів з високою чутливістю та широким спектром частот. Метод дозволяє фіксувати часову діаграму, пропорційну акустичному шуму, який викликаний запальними процесами та виникає при диханні. Недоліками методу та його реалізації $€$ те, що діагностується лише вид бронхолегеневої патології, а виявити, у якій частині дихальної системи знаходиться патологія, неможливо. Трубку із загубником, в якій розташовано датчик, неможливо пристосувати до немовлят, а використовувана в цій ситуації маска може спричиняти незручності - малі діти та непритомні пацієнти не можуть контролювати дихання.

Підводячи підсумки, маємо наступні проблеми, які потребують вирішення: дослідження повинно бути безпечним, швидким та зручним для усіх вікових категорій; отримані сигнали мають бути досить інформативними для способу пасивної ехолокації; мають вилучатися з основного сигналу сторонні шуми; підсилення складного сигналу повинне бути без порушення його амплітудно-частотних характеристик.

Мета роботи: створення спеціальної системи для автоматизації процесу аускультації і реалізації способу діагностики пневмонії пасивною ехолокацією.

Матеріали та методи дослідження. Для того, щоб вирішити поставлені задачі, по-перше, треба вирішити, у який спосіб діагностична система отримуватиме інформацію від тіла пацієнта. Для реалізації способу діагностики пасивною ехолокацією потрібен акустичний сигнал, що надходить відразу з декількох датчиків, які розташовуються навколо грудної клітки. Далі сигнал має підсилюватись, фільтруватись та перетворюватись з аналогового на цифровий і проходити подальшу обробку обчислювальною системою за допомогою програмного забезпечення. Спосіб пасивної ехолокації відповідає вимогам безпеки.

На рис. 3 представлена структурна схема діагностичної системи для реалізації способу пасивної ехолокації.

Матриця акустичних датчиків являє собою набір мікрофонів, що закріплюються на поверхні шкіри пацієнта навколо грудної клітки. Таке розташування датчиків дозволяє приймати акустичні сигнали, утворювані патологією всередині тіла пацієнта, одночасно з різних аускультативних точок. Кожен 3 датчиків має віртуальну координату $\mathrm{D}(\mathrm{x}, \mathrm{y}, \mathrm{z})$. Завдяки цьому у програмному забезпеченні комп’ютера відбувається розрахунок положення у віртуальному просторі джерела шуму.

Для найбільш зручної у використанні форми матриці акустичних датчиків та змоги використання iї у немовлят і дітей молодшого віку, мікрофони мають бути як змога меншими. Уся конструкція, 


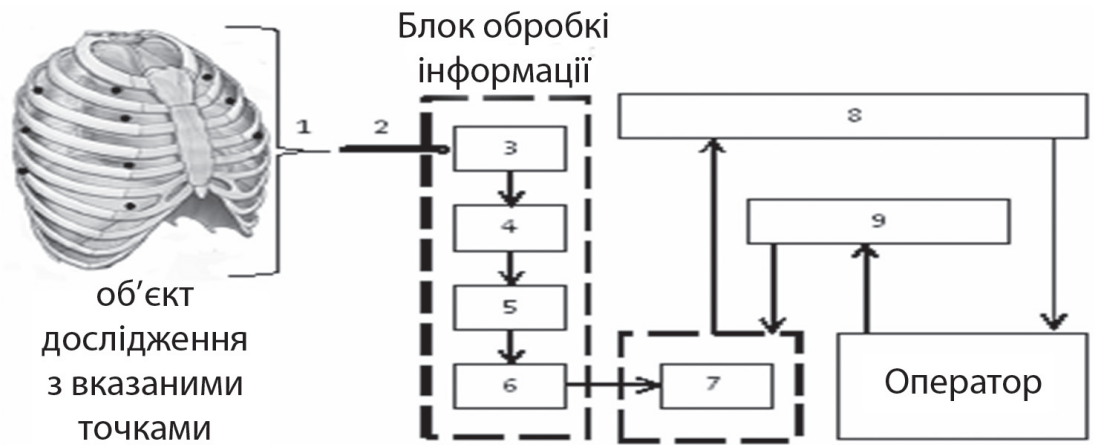

Рис. 3. Структурна схема діагностичної системи для реалізації способу діагностики пневмоній: 1 - матриця акустичних датчиків, що накладається на грудну клітку пацієнта; 2 - шина передачі акустичного сигналу;

3 - мультиплекс; 4 - підсилювач; 5 - набір акустичних фільтрів; 6 - аналого-цифровий перетворювач;

7 - програмне забезпечення комп’ютеру; 8 - блок графічного відображення; 9 - блок керування

при закріпленні на тілі, не повинна заважати рухам або диханню. Мікрофон, який найбільш підходить за характеристиками - MEMS Analog Devices ADMP801 [10]. Розміри цього мікрофона становлять лише $3,35 \times 2,5 \times 0,9$ мм. Крім того, він має переваги перед звичайними електретними мікрофонами: стійкий до дії зовнішнього середовища, має низький рівень шуму, що дуже актуально в діагностиці бронхолегеневих захворювань, характеризується дуже низьким рівнем енергоспоживання (17 мкА при напрузі 1В). Даний мікрофон призначений для використання у слухових апаратах, але може використовуватись і в інших медичних пристроях завдяки малим розмірам, зручності монтажу та іншим вказаним перевагам.

Блок обробки містить послідовно поєднані мультиплексор, підсилювач і набір акустичних фільтрів і поєднаний з набором акустичних датчиків шиною. У цьому блоці акустичний сигнал

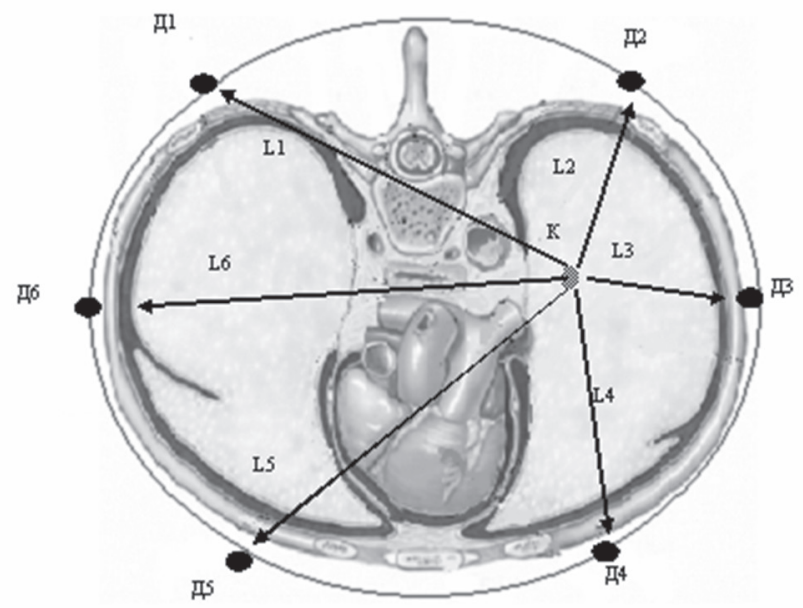

Рис. 4. Схематичне зображення розташування датчиків (Дn), джерела шуму (K) та напрямків руху шуму до датчиків всередині тіла пацієнта (Ln) у поперечній площині
3 датчиків обробляється для наступної передачі до комп’ютеру.

Мультиплексор призначено для почергового перемикання між мікрофонами. Це дає змогу підключати діагностичну систему до цифрового входу мікрофону на комп'ютері. Черговість та швидкість перемикання між датчиками керується блоком керування.

Підсилювач у цій схемі потрібен для підсилення акустичного сигналу. Основною проблемою використовуваних у медичній техніці підсилювачів $\epsilon$ низька точність підсилення через методичну похибку та похибки несиметрії системи, відсутність можливості налаштування необхідного загального коефіцієнта підсилення, відсутність врахування фазового зсуву та частотного діапазону перетворення, неможливість спряження аналогових та цифрових компонентів. Для запобігання зазначених недоліків найкраще для діагностичної системи використати підсилювач напруги з адаптивним коефіцієнтом перетворення [6]. Вказаний підсилювач дає змогу налаштовувати коефіцієнт підсилення та характеризується широким частотним діапазоном і мінімальним фазовим зсувом, що є дуже важливим для ідентифікації дихальних шумів, та пошуку їх на ранніх стадіях захворювання.

Набір акустичних фільтрів існує для зручності виділення необхідних діапазонів. Для аналізу використовується загальний діапазон від 200 Гц до 12600 Гц. У свою чергу, для зручності аналізу отриманого сигналу, останній розподіляється набором акустичних фільтрів на три діапазони. Перший діапазон від 200 Гц до 1200 Гц - сюди потрапляє везикулярне та саккадоване дихання. Другий діапазон має межі від 1200 Гц до 5000 Гц - тут прослуховуються шуми тертя плеври. Та третій діапазон 
від 5000 Гц до 12600 Гц - до нього потрапляють бронхіальне дихання та крепітації. При цьому нормальне дихання прослуховується на частотах від 180 Гц до 350 Гц. Різноманітні хрипи прослуховуються на усіх трьох частотах $[3,4,8]$.

Аналого-цифровий перетворювач, що розташований після набору акустичних фільтрів, необхідний для перетворення сигналу з аналогового на цифровий. Це робиться для того, щоб підготувати сигнал до передачі у програмне середовище комп’ютера.

Після перетворень у блоці обробки акустичний сигнал потрапляє до комп’ютеру, де у програмному середовищі проходить остаточну обробку згідно зі способом діагностики пневмоній методом тривимірної візуалізації.

Прослуховування та запис акустичних феноменів проходить у зручному для пацієнта положенні тіла, не викликає неприємних відчуттів. Дослідження проводиться безперервно, до тих пір, доки не будуть отримані дані, достатні для розпізнавання акустичних феноменів, якщо вони відбуваються.
Але дослідження триває не більше декількох хвилин, щоб запобігти спричиненню незручностей пацієнту. Надалі аускультацію можна припинити та розпочати проведення обробки отриманого сигналу.

Пристрій для діагностики пневмоній працює наступним чином. Сигнал запального процесу формується всередині грудної клітки пацієнта. Мікрофони матриці 1 датчиків сприймають цей сигнал. 3 мікрофонів сигнал надходить на шину 2, яка поєднана з мультиплексором 3 всередині блоку обробки. 3 блоку обробки мультиплексор 3 керує почерговим перемиканням мікрофонів. Сигнал з кожного окремого мікрофона почергово проходить через мультиплексом 3 та спрямовується на підсилювач 4, де підлягає підсиленню. Далі сигнал потрапляє у набір акустичних фільтрів 5. У цьому блоці сукупний сигнал розподіляється на 3 діапазони, зазначені вище. Після цього кожен 3 діапазонів сигналу підлягає перетворенню 3 аналогового на цифровий у аналого-цифровому перетворювачі 6, з якого вже направляється до

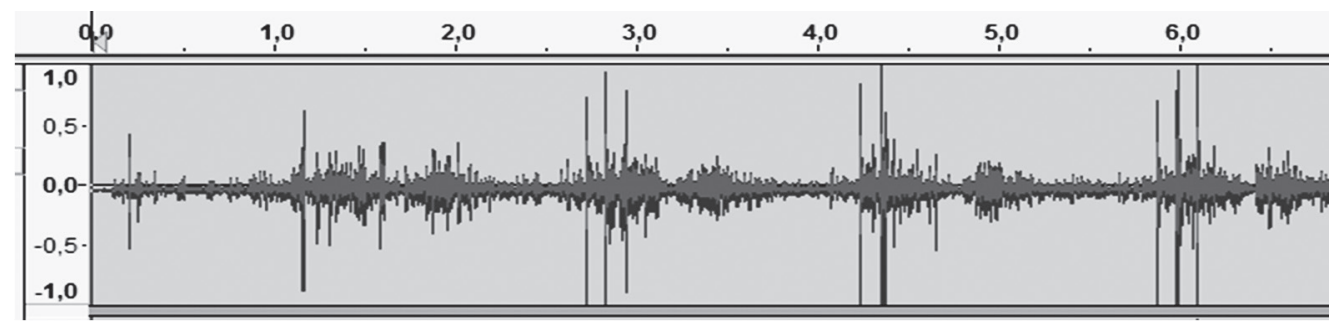

Рис. 5. Відображення отриманого за допомогою діагностичної системи дихального патерну, що містить крепітації

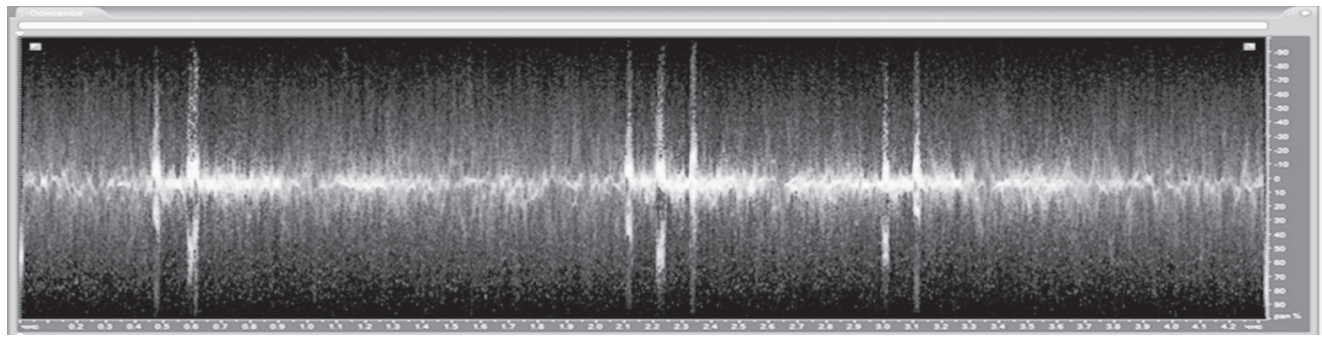

Рис. 6. Спектр дихального патерну (рис. 5), що містить крепітації

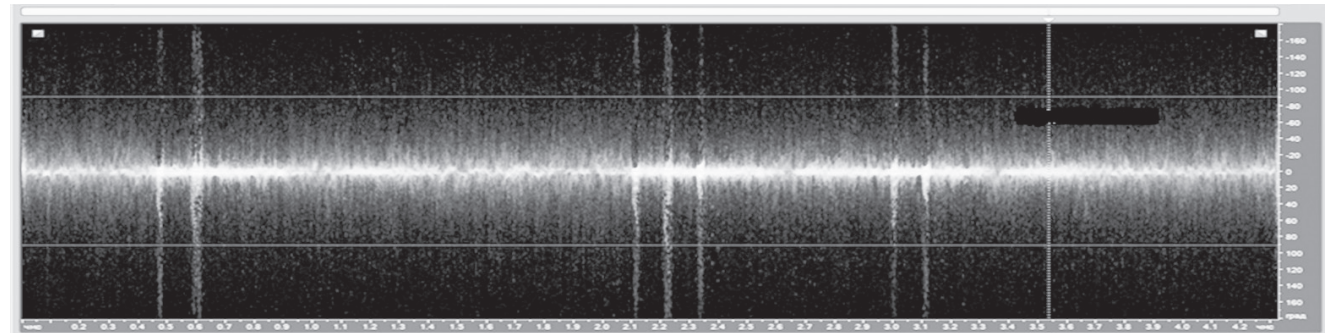

Рис. 7. Спектр дихального патерну еталону, що містить крепітації 
комп’ютеру. Програмне забезпечення 7, що знаходиться у комп’ютері, отримує сигнал від блоку обробки. Сигнал у програмному забезпеченні обробляється під керуванням оператора. Оператор керує остаточною обробкою сигналу у програмному забезпеченні 7 через блок керування 9. Після закінчення обробки сигналу отримані дані потрапляють на блок графічного відображення 8, де лікар може їх ідентифікувати. Запис аудіофайлів здійснюється у форматі МР3.

Оцінка роботи пристрою проводилась порівняльним аналізом отриманих акустичних сигналів з еталонами, які використовуються для навчання студентів медичних вузів та для підвищення кваліфікації лікарів [1].

Результати та їх обговорення. На рис. 5 представлено акустичний запис дихального патерну, отриманого за допомогою описаної в цій статті діагностичної системи. Запис було розкладено на спектр і результат представлено на рис. 6.

Якщо зіставити за допомогою автокореляційної функції спектри, представлені на рис. 6 та рис. 7, можна побачити, що їх образи збігаються. Така збіжність свідчить про високу чутливість діагностичної системи до слабких шумів дихального патерну та правильну її роботу.

Висновки. Отримані результати акустичних сигналів відповідають даним класифікації аускультативних шумів $[3,4,8]$. Така відповідність дає змогу зробити висновок, що розроблене обладнання у повній мірі реалізує поставлені задачі.

Пристрій для діагностики пневмоній при реалізації має суттєві переваги характеристик. Невеликі розміри датчиків надають можливість проводити діагностику пневмоній у новонароджених та дітей молодшого віку. Пристрій надає можливість отримувати більш достовірну інформацію, що відображає усю картину обструктивного захворювання легенів, вже на першому обстеженні дозволяє отримати достовірний результат без проведення додаткових досліджень.

Запропоноване рішення ефективно вирішує поставлені завдання, а саме: система пристосована до роботи з методом пасивної ехолокації та є зручною для пацієнтів будь-якого віку; використання набору акустичних фільтрів, підсилювача та подальшої програмної обробки у купі дало змогу позбавлятися від зайвих шумів; набір акустичних фільтрів дозволяє підвищити точність за рахунок розподілу сукупного сигналу на окремі частоти з відсіканням частот кардіальних шумів; використання підсилю- вачів для кожної окремої частоти сигналу запобігає порушенню амплітудно-частотних характеристик; проведення дослідження цілком безпечно для пацієнта.

\section{Література.}

1. Аускультация легких [Электронный ресурс]/ Emergency Medical Help. - Режим доступа : http://www. emhelp.ru/

2. Восканян А. Г. Пневмония. Особенности течения и лечение больных астмой [Электронный ресурс] / А. Г. Восканян, А. А. Восканян // Электронный научный журнал «Современные проблемы науки и образования». - 2007. - № 6 (часть 2). - С. 20-32. - Режим доступа : http://www.science-education.ru/24

3. Катилов А. В. Дискуссионные вопросы методики оценки аускультации лёгких у детей / А. В. Катилов, С. В. Зайков, Д. В. Дмитриев // Дитячий лікар. - 2011. - № 5 (12). - С. 19-26.

4. Манджони С. Секреты клинической диагностики / С. Манджони ; пер. с англ. - М. : БИНОМ, 2004. - 608 с. 5. Пат. № 2354285 С1 РФ, МПК А61В5/00, A61B5/08. Способ акустического спектрального анализа обструктивных заболеваний легких / Гусейнов А. А.; заявитель и патентообладатель ГОУ ВПО «ДГМА ФАЗ СР». - № 2007133969/14; заявл. 11.09.07; опубл. 10.05.2009, Бюл. № 13.

6. Пат. України № 86534 U, МПК Н03F 5/00, Н03Н 11/00. Підсилювач напруги з адаптивним коефіцієнтом перетворення / Сліпченко М. І., Федотов Д. М., Федотов Д. О., Крук О. Я.; заявник та патентовласник Харківський національний університет радіоелектроніки. № u201302919 ; заявл. 11.03.2013 ; опубл. 10.01.2014, Бюл. № 1.

7. Пневмония [Электронный ресурс] / ВОЗ (официальный сайт). - Информационный бюллетень № 331. - Ноябрь 2015 г. - Режим доступа : http://www.who.int/mediacentre/ factsheets/fs331/ru/

8. Проблемы регистрации и классификации шумов дыхания человека / И. В. Вовк, В. Т. Гринченко, Л. Г. Красный, А. П. Макаренко // Акустический журнал. - 1994. - Т. 40, № 1. - С. 50-60.

9. Справочник педиатра / [В. Г. Арсентьев, О. О. Булыгина, Н. В. Гончар и др.] ; под ред. проф. Н. П. Шабалова. - СПб. : Питер, 2014. - 3-е изд. - (Серия «Спутник врача»). - С. 412-418.

10. ADMP801 Hearing Aid Omnidirectional MEMS Microphone [Electronic resource] / Med Device Online. - Retrieved from : http://www.meddeviceonline.com/doc/ admp-hearing-aid-omnidirectional-mems-microphone-0001 11. Locaphony - new acoustical method of express functional medicine diagnostics / V. Svet, J. Blinkov, S. Nikolaev, V. Murashev // XI Session of the Russian Acoustical Society. Moscow, November 19-23, 2001. 


\section{References.}

1. Lungs auscultation. Retrieved from Emergency Medical Help http://www.emhelp.ru/ [In Russian].

2. Voskanyan, A. G., Voskanyan, A. A. (2007). Pnevmoniya. Osobennosti techeniya i lechenie bol'nykh astmoi [Pneumonia. Features of the course and treatment of patients with asthma]. E-journal Sovremennye problemy nauki i obrazovaniya (Problems of modern science and education), 6(part 2), 20-32. Retrieved from http://www. science-education.ru/24 [In Russian].

3. Katilov, A. V., Zaikov, S. V., Dmitriev, D. V. (2011) Diskussionnye voprosy metodiki otsenki auskul'tatsii legkikh u detei [Discussion on the assessment of lung auscultation in children]. Dityachii likar, 5(12), 19-26 [In Russian].

4. Mandzhoni S. (2004) Sekrety klinicheskoi diagnostiki [Secrets of clinical diagnostics]. Moscow: BINOM [In Russian].

5. Guseinov, A. A. (2009). Sposob akusticheskogo spektral'nogo analiza obstruktivnykh zabolevanii legkikh [Method of spectral analysis of acoustic obstructive pulmonary disease]. Pat. No. 2354285 S1 RF, MPK A61V5/00, A61V5/08 [In Russian].

6. Slipchenko, M. I., Fedotov, D. M., Fedotov, D. O., Kruk, O. Ya. (2014). Pidsilyuvach naprugi z adaptivnim koefitsiientom peretvorennya [Amplifier with adaptive voltage conversion ratio]. Pat. Ukraine No. 86534 U, MPK H03F 5/00, H03H 11/00 [In Ukrainian].

7. Pneumonia. Fact sheet $\mathrm{N}^{\circ} 331$. Retrieved Nov 2015 from WHO Media centre, http://www.who.int/mediacentre/ factsheets/fs331/ru/ [In Russian]/

8. Vovk, I. V., Grinchenko, V. T., Krasnyi, L. G., Makarenko, A. P. (1994). Problemy registratsii i klassifikatsii shumov dykhaniya cheloveka [Problems of registration and classification of human breath noise]. Akusticheskii zhurnal (Acoustical Physics), 40(1), 50-60 [In Russian].

9. Shabalov, N. P. (Ed.). (2014). Spravochnik pediatra [Pediatrician handbook] (3rd ed.). St. Petersburg: Piter [In Russian].

10. ADMP801 Hearing Aid Omnidirectional MEMS Microphone. Retrieved from Med Device Online, http:// www.meddeviceonline.com/doc/admp-hearing-aidomnidirectional-mems-microphone-0001

11. Svet, V., Blinkov, J., Nikolaev, S., Murashev, V. (2001, November 19-23). Locaphony - new acoustical method of express functional medicine diagnostics. XI Session of the Russian Acoustical Society. Moscow. 